\title{
小児尿路結石17症例の経験
}

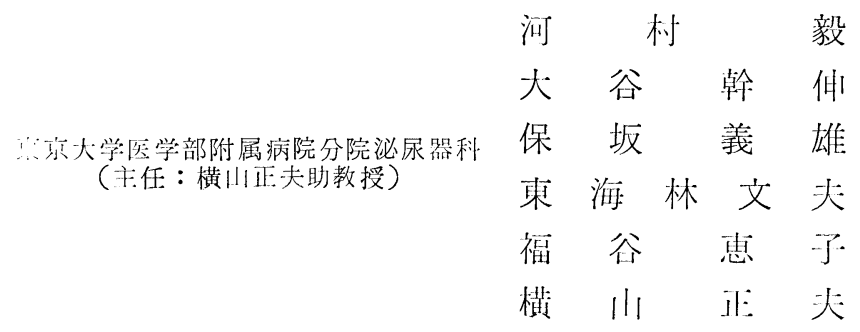

\section{SEVENTEEN CASES OF UROLITHIASIS IN CHILDREN}

Takeshi Kawamura, Mikinobu Ohtani, Yoshio Hosaka, Fumio Shoji, Keiko Fukutani and Masao Yokoyama

Department of Urology, Branch Hospital, Faculty of Medicine, The University of Tokyo

(Director: Associate Professor M. Yokoyama)

During the last 15 years (1965.1-1979.12), we have experienced 17 cases of urolithiasis in children under 15 years of age. Childhood urolithiasis was rare and occupied 1.6\% of 1047 urolithiatic patients of all ages during the same periods. There were 12 boys and 5 girls. The sex ratio was 2.4 to 1 . The youngest case was 8 month-old and the eldest was 15 year-old. Eight cases $(47 \%)$ were under 5 years-old. Thirteen patients had stones in the upper urinary tract (9 in the kidney and 4 in the ureter), 2 in the lower tract ( 2 in bladder) and 2 in both upper and lower tracts ( 1 in the ureter and bladder, 1 in the ureter and urethra), respectively. Signs and symptoms were gross total hematuria in 6 cases, fever in 3, flank pain in 3, vesical irritation in 3, urinary retension in 1 and urinary incontinence in 1 . Thirteen operations were performed in 11 patients with stones in the upper urinary tract. The nephrectomy was done in two patients and the kidney was conserved in 9 patients. Ten stones were analysed by infrared spectrography. There were 4 phosphate containing calculi, 3 oxalate containig ones, 2 cystine stones and 1 xanthine stone. Predisposing factors for stone formation were assumed in 9 cases $(52.9 \%)$ : Cystinuria in 2 cases xanthinuria in one case, urinary tract obstructions and/or infections in 3 cases, side effects of drugs administered to underlying diseases in 2 cases and longterm immobilization in one case. Of 12 cases successfully treated to the stone free conditions, only one patient recurred the stone during the follow-up period of averaging 9.6 years. The recurrence rate was $8.3 \%$, which was significantly lower than those of adult cases. A complete urographic study is necessary for early diagnosis of pediatric urolithiasis. Abdominal CT scan may be of great help in the case of $\mathrm{X}$-ray negative stones. A thorough search for predisposing factors is important in children, since metabolic disorders and urinary tract obstructions are prevalent in pediatric urolithiasis.

要旨 : 昭和 40 年から昭和 54 年までの 15 年間に東大分院泌尿器科であつかつた15歳以下の小监尿路結石症は 17 名 で，この間の全結石症例の $1.6 \%$ に相当した．性別は男 12 ，女 5 で男女比は $2.4: 1$ であつた．年齢は最年少が 8 カ月, 8 例が 5 歳以下で最年長に15歳であつた。結石部位は上部結石 13 例（腎結石 9 ，尿管結石 4 ), 下部 結石 2 例（膀胱結石 2 ），上部と下部結石合併 2 例（尿管と膀胱結石 1 ，尿管と尿道結石 1 ）であつた. 臨床 症状は肉眼的血尿 6 例, 発熱 3 例, 側腹痛 3 例, 膀脂刺激症状 3 例, 尿閉 1 例, 尿失禁 1 例とさまざまであつ た. 上部結石 13 例のうち観血的治療を㧍こなつたのは11例，13回でこのうち腎摘例が 2 例で腎保存出来たも のは 9 例であつた. 10例飞結石成分の分析を掞こない粼酸塩系結不 4 , 蓚酸塩系 3 , シスチン 2 , キサンチン 
1 例であつた. 原因疾患の判明したものは 9 例, $52.9 \%$ で，その内訳はシスチン疗症 2 , キサンチン疗症 1 , 尿路奇形之感染 3 ，長期臥床 1 ，薬剤の副作用 2 例であつた．結石 free の状態となつた 12 例の平均追跡期間 は9.6年で,この間の再発は1例のみで再発率は8.3\%であつた.

小児尿路結石症は結石の早期診断と原因疾患の検索が必要であり，このためには前もつてたてたスケジュー ルにしたがつて原因疾患の検索をおこなら必要がある。またX線院性結石の疑いのある場合には腹部 CTが診 断上有用である.

\section{はじめに}

小児の尿路結石症（以下尿石症と略）は発生頻度こそ 低いが成人例に比較し発症原因を有していることが多 く，成人例とは区別しその病因を詳細に検索する必要が あるといわれている(1)2)。乙かし本邦では小児尿石症の まとまつた報告が少ないので，東大分院で経験した小児 尿石症17例につき検討を加え報告する。

\section{対象および結果}

昭和 40 年 1 月より 54 年 12 月までに東大分院泌尿器科外 来を受診した尿石注患者は1,047名で15歳以下の小児例

表 1 結住患者数（1965．1～1979，12）

\begin{tabular}{l|c|c|c}
\hline & 男 & 女 & 計 \\
\hline 全結石症例数 & 758 & 289 & 1047 \\
\hline 小览結石症例数 & 12 & 5 & 17 \\
\hline $\begin{array}{c}\text { 小児結石症例数/ } \\
\text { 全結石症例数 } \\
(\%)\end{array}$ & 1.6 & 1.7 & 1.6 \\
\hline
\end{tabular}

は17名である（表1）。この17例の概要を表 2 に示し た.なお 1 個の結石が 2 力所以上の大腎杯にわたつて存 在しているものをサンゴ状結石とした。

頻度・年㱓・男女比：小児尿石症の全尿石症に対寸る 比率は1.6\%であつた。

1 歳以下は 2 例, 1 歳から 5 歳までが 6 例， 6 歳から 10 歳までが 6 例， 10 歳台は 3 例で，5歳以下の就学前の 小奣が $47.1 \%$ をめた. 性別は男12例, 女 5 例で男女比 は2.4：1であつた（表 1).

結石部位: 上部尿石が13例, 下部尿石が 2 例, 上部之 下部共存が 2 例であり, 上部尿石と下部尿石の比率は 6.5：1であつた. 上部尿石13例の内訳は腎結石 9 例 (古側 3, 左側 4, 両側 1) であり下部尿石は膀脱結石 2 例であつた。腎結石のうちサンゴ状結石が 6 例で 66.7 \%と高率をしめており右側 1 , 左側 4 , 両側 1 であつ た.

臨林症: 状 :

症状は時に 2 つ以上のこともあるが，1 症例 1 主訴と

表 2 小児結石 17 例の概要

\begin{tabular}{|c|c|c|c|c|c|c|c|c|c|c|c|}
\hline 症例 & 氏名 & 年令 & 性 & 初発症.状 & 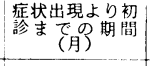 & 診 断 & 処㯰 & 結石成分 & 原因䓡患 & 秸石 & 要発の \\
\hline 1 & 金O 節O & 6 & $\mathrm{~F}$ & 膀胱刺激症状 & 3 & 膀胱結石 & 膀胱切石術 & シスチン & シスチン尿症 & 有 & 無 \\
\hline 2 & 長○ 達O & 9 & $\mathrm{M}$ & 肉眼的血尿 & 24 & 右サンゴ状結石 & 右堅摘除術 & 葆酸 $\mathrm{Ca} \cdot$ 燐酸 $\mathrm{Ca}$ & 無 & 無 & 有 \\
\hline 3 & 石○ 忍 & 5 & $\mathrm{M}$ & 肉眼的血尿 & 9 & 両側サンゴ状結石 & 放真 & & 無 & 無 & 不明 \\
\hline 4 & 広O & 3 & $\mathrm{M}$ & 膀胱刺激症状 & 6 & 膀胱結石，右尿管結石 & '膀腃切石術, & & $\begin{array}{l}\text { 右発育不全腎 } \\
\text { 路感架 }\end{array}$ & 無 & 無 \\
\hline 5 & 高O & $10 \mathrm{M}$ & $\mathrm{M}$ & 発熱 & 18 & 左サンゴ状䊅石 & 左腎孟切石術 & 落酸 $\mathrm{Ca}$ & 無 & 無 & 無 \\
\hline 6 & 南○ 元○ & 4 & $\mathrm{~F}$ & 膀胱刺激症状 & 1 日 & 膀胱結石 & 自然排出 & & 不明 & 無 & 無 \\
\hline 7 & 長○雄○彰 & 6 & $\mathrm{M}$ & 肉眼的血尿 & 9 & 左サンゴ状結石 & 左腎・堅杰切石術 & リン酸 Mg アンモニウム & 無 & 無 & 無 \\
\hline 8 & 新○ 缓○ & 15 & $\mathrm{~F}$ & 肉眼的血尿 & 12 & 右留結石 & 右腎部分切除術 & 落酸 $\mathrm{Ca}$ ・燐酸 $\mathrm{Ca}$ & $\begin{array}{l}\text { VD抵抗性クル病 } \\
\text { VD量投与 }\end{array}$ & 無 & 無 \\
\hline 9 & 中O 澄O & 15 & $F$ & 側腹痛 & 3 & 右尿管結石 & 右尿管切石術 & シスチン & シスチン尿症 & 無 & 無 \\
\hline 10 & 舘O 茂 & 9 & $\mathrm{M}$ & 側腹痛 & 7 & 右尿管結石 $\rightarrow$ 尿道結石 & 膀胱切石術 & キサンチン & キサンチン尿症 & 無 & 無 \\
\hline 11 & 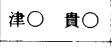 & 6 & $\mathrm{M}$ & 尿失禁 & $?$ & 左サンゴ状結石 & 放置 & & 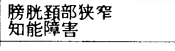 & 無 & 無 \\
\hline 12 & 荒O 周O & $8 \mathrm{M}$ & $M$ & 発熱 & 15日 & 尿道結石，左永管結石 & 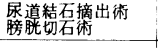 & リン酸 Ca & 無 & 無 & 無 \\
\hline 13 & 熊○理○子 & 3 & $\mathrm{~F}$ & 肉眼的血尿 & 1 & 右眮結石 & 放置 & & 形成不全性贫血 & 無 & 無 \\
\hline 14 & 川O 正O & 3 & $\mathrm{M}$ & 尿閉 & 36 & 左尿管結石 & $\begin{array}{l}\text { 左精車腺剔除 } \\
\text { 管切石逨 } \\
\end{array}$ & リン酸 Ca & $\begin{array}{l}\text { 右掔资挰左 VUR } \\
\end{array}$ & 無 & 無 \\
\hline 15 & 小○保○輔 & $1 才 2 \mathrm{M}$ & $\mathrm{M}$ & 発熱 & 6 & 左サンゴ状結石 & 左腎孟切石術 & リン酸 Mgアンモニウム & 無 & 無 & 無 \\
\hline 16 & 島O 直O & 8 & $\mathrm{M}$ & 側腹痛 & 9 日 & 右尿管結石 & 自然排出 & & 無 & 無 & 無 \\
\hline 17 & 板 $\bigcirc$ 直O & 11 & $\mathrm{M}$ & 肉眼的血尿 & 2 & 右肎結石 & 放置 & & $\begin{array}{l}\text { 告婜欠㨐, 側峦症 } \\
\text { 知能害 }\end{array}$ & 無 & 無 \\
\hline
\end{tabular}


図 1

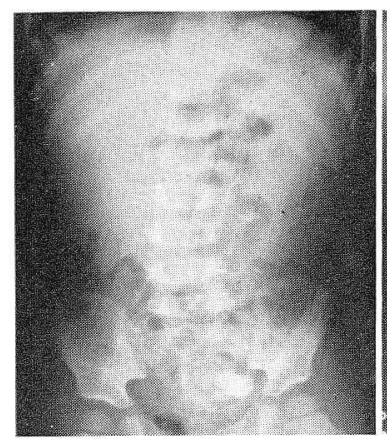

図 1 症例 140 術前 KUB. 左尿管下端に結石陰影加 双られる。

図 2 症例 140 術前 IVP. 右腎欠損, 左尿管下端狭 窄による水腎水尿管と下端結石がみられる。

圃 3
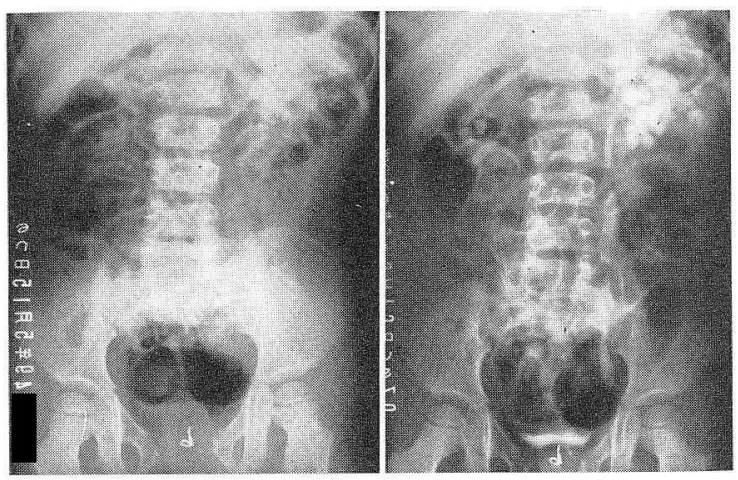

図 3 症例11の初診时 KUB，左腎部にサンゴ状陰 がみられる。恥骨結合は唯開し, 膀胱澒部形成術の 際の縫合に使用したと思われる鋼線がみられる。

図 4 症例 11 の初診時 IVP. 左サンゴ状結石による 左水腎症が存在与る。

図 5
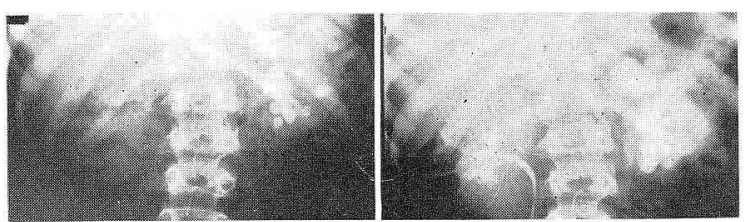

図 5 症例11の 6 年目の KUB。 左サンゴ状結石の増 大と院影の增強がみられる。

図 6 症例11の 6 年目のIVP. 左水腎症の增雭が东 られる。膿水であるが発熱発作はなく知能障害があ るため現在経過観察中である。

図 7

为 8

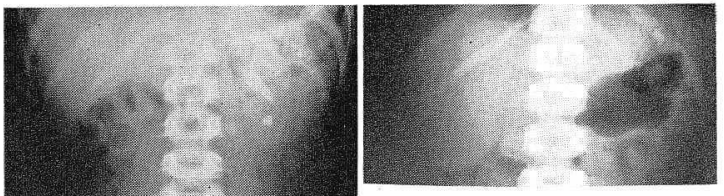

図 9

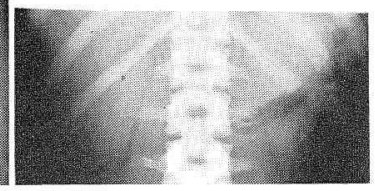

図7 症例 7 の術前 KUB. 左腎部にサンゴ状陰路が 欢占れる。

図 8 症例 7 の術直後 $\mathrm{KUB}$. 左腎部下極に $7 \times 4 \mathrm{~mm}$ の残石がみ゙ら机る。

図 9 症例 7 の術後 11 年目の KUB. 左㿡部に $10 \times 6$ $\mathrm{mm}$ の結石があり，11年間でその大ささは汪とんど 変わつていない。

図 10

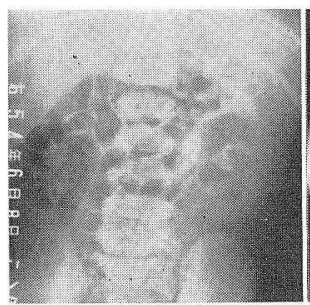

図10 症例 15 \% KUB。明膫な結石陰路は描出されて いない.

図11 症例15の腹部 CT. 左腎盂・腎杯内に存在する 結石が明膫に描出されている。

図 11

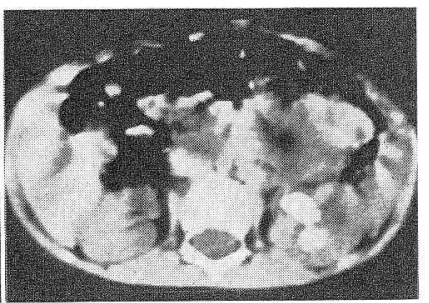


して整理してみると，上部尿石13例では肉眼的血尿 6 例，発熱 2 例，側腹痛 3 例，尿閉 1 例，尿失禁 1 例であ つた。

尿閉を主訴とした症例14は左精䅇腺囊腫の圧追による 尿閉で，検査により右腎欠損，左膀脱尿管移行部狭窄に よる左水腎・水尿管をともなら左尿管結石が発見された 例である ${ }^{3)}$. 図 1 和よび 2 はこの症例の術前 KUB, IVP 像である，尿失禁を主訴とした症例11は生下時より尿閉 で某大学病院で生後10日目に膀脂頝部閉塞症の診断で膀 脱頝部形成術をうけ，以後尿失禁となり 6 歳の時尿失禁 治療の目的で当科を受診し左サンゴ状結石が発見された 例であつた。図 3 および 4 は症例11の KUB，IVP 像で ある. 下部尿石 2 例の症状はともに脖脱刺激症状であ り，上部と下部合併尿石 2 例は発熱 1 例，膀胱刺激症状 1 例であつた。

初発症状出現から当科受診までの期間：17例はすべて 当院他科または他医院からの紹介例である. 症例 6 では 当日, 症例 16 では 9 日と初発症状出現後短期間侵診し た例もあるが，多くはかなり経過を経てから紹介されて 括り平均期間は8.6力月であつた。症例15は生後 6 力月 頃より発熱と膿尿をくりかえしX線検查で診断がつかず 1 歳 2 力月の時当科に紹介され，腎膀朕部単純撮影で困 10亿示すように結石陰影は不明であつたが腹部 CT で図 11 亿示すようにサンゴ状結石の存在をみとめ, 初発症状 出現より 6 カ月後に䛦断し得た症例であつた。な和症例 11は主訴が尿失禁で結石は無症状のため平均期間の算出 から除外した。

治療：17例中 2 例（症例 $6 ， 16 ）$ の疗石が自然排出し た. 11例に観血的治療を抏こなつた. 残りの 4 例のうち 3 例が経過観察中（症例11，13:6 年間，症例17：1 年 間)であり，1例（症例 $3:$ 両側サンゴ状絬石）は 1 年 後追跡不能となつた.

観血的治療をうけた11例の13回の手術の内訳は腎摘除 術 2 例，腎部分切除術 1 例，腎・腎孟切石術 1 例，腎孟 切石術 2 例，尿管切石術 2 例，膀脂切石術 4 例，尿道絬 石摘出術 1 例であつた。

術後残石をみとめたのは症例 7 の 1 例のみであつた.

結石成分：10例の結石成分を赤外線分光分析法により 調ベた. 葆酸カルシウム・燐酸カルシウム混合結石 2 例，蓚酸カルシウム結石 1 例，燐酸マグネシウム・アン モニウム結石 2 例，シスチン結石 2 例，キサンチン結石 1 例であつた（キサンチン結石症例の詳細は既に報告し $\left.た^{(4)}\right)$.
原因疾患：結石発症の原因疾患が明らかなものは17例 中 9 例 $52.9 \%$, 見出せなかつたもの 7 例 $41.2 \%$ であつ た. 症例 6 は未検查のため不明とした。9 例の原因疾患 の内訳はシスチン尿症 2 例, キサンチン尿症 1 例, 薬剂 の副作用 2 例, 長期臥床 1 例, 尿路奇形をともなら尿流 停滞，尿路感染によるもの 3 例であつた。

家族発生：

17例中家族歴で親族に結石の発症を久たものは症例 1 のシスチン尿症例のみで, 他に家族発生したものはなか つた.

\section{経過ならびに再発}

結石 free の状態となつた12例中積極的に再発予防を 扣こなつたのは症例 9 のシスチン疗症に対し重曹と一将 期 D-penicillamine を投与した1例のみであつた。他の 11 例は水分多量摂取の指導以外特別な処置をおこなつて いなかつた.これら12例のその後の経過をみると平均追 跡期間は9.6年で，この間の再発例は症例 2 の 1 例のみ であつた.

怔例 7 は钼血的治㙩の残石例であるが術後11年で残石 の大ささは不変であり，新たな結石の出現はみられな かつた。図 7 は術前，図 8 は術任後，図 9 は11年目の KUBである.

無処置群 4 例山追跡不能 1 例（怔例 3 ）を除く 3 例は 水分摂取と尿路感染のコントロールで現在経過観察中で ある. 既存の結石が少しずつ増大しているが新たな結 石の形成はない。図 5,6 は症例 11 の 6 年目の KUB, IVP である.

\section{考按}

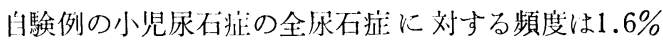
であつた。これは最近の本邦に拁ける他の報告例 ${ }^{56)}$ の 頻度とほほ同じ傾向で，小児尿石症の発生頻度が非常に 低いことを示している.

男女比は自験例で $2.4 ： 1$ と男児に多く, 本邦の諸家 の報告(6)7 8) ${ }^{8}$ 一一致している。 また当科の尿石全体の男女 比2.6：1 とも注涪同じ比率であつた（表 1). 欧米の教

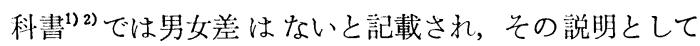
小児ではテストステロンの分泌やクエン酸塩排泄に男女 差がないためとしている。 しかし個々の論文をみると男 女差がないとの報告 ${ }^{910) 11)}$ もあるが，Myers ${ }^{12)}$ の52： 33 (1.6:1), Ghazali ら ${ }^{13)}$ の0:30 (3:1), Malek and Kelalis ${ }^{14)}$ の9:29 (1.7: 1)，と男児が優位とする 報告が多い. 自験例の年龄別頻度をみると 5 歳以下が $47.1 \%$ 半数近くを占め 1 歳未満が 2 例にみられた。こ 
れは本邦報告例 ${ }^{56778)}$ 比較すると若年化傾向を示した. しかし欧米の報告をみると Bass and Emanue ${ }^{10)}$ は 5 歳 以下が53.3\%， Myers ${ }^{12}$ は63.5\%で 1 歳以下が10.6\%と より若年化がすすんでいる．この差の要因の一つは後述 するように初発症状出現から確定診断までの遅れによる と考えられる.

われわれの症例では上部尿石と下部尿石の 比は6.5： 1 で上部尿石が圧倒的に多かつた. 小児尿石の上部対下 部尿石の比率を1900年代初期から今日にいたるまでの本 邦, 欧米先進国, 結石多発地带 (epidemic stone area) の怙もな報告例につき調べ表 3 に示した。本邦では1960 年頃まで下部尿石優位であつたが1970年藤沢ら ${ }^{7)}$ の報告

表 3 世界各地に的ける小児尿石症の上部尿石と下 部尿石の比率の年代的推移

\begin{tabular}{|c|c|c|}
\hline & 上部尿石 & 下部尿石 \\
\hline \multirow{2}{*}{$1915 \sim 1954^{151}$} & 5 & 42 \\
\hline & \multicolumn{2}{|c|}{$(1: 8.4)$} \\
\hline \multirow{2}{*}{$1925 \sim 1958^{151}$} & 1 & 24 \\
\hline & \multicolumn{2}{|c|}{$(1: 24)$} \\
\hline \multirow{2}{*}{$1959 \sim 1975^{61}$} & 10 & 4 \\
\hline & \multicolumn{2}{|c|}{$(2.5: 1)$} \\
\hline \multirow{2}{*}{$1966 \sim 1975^{81}$} & 8 & 2 \\
\hline & \multicolumn{2}{|c|}{$(4: 1)$} \\
\hline
\end{tabular}

\begin{tabular}{l|c|c} 
欧米先進国 & 上部尿石 & 下部尿石 \\
\hline & 64 & 2 \\
\hline $1929 \sim 1943^{161}$ & \multicolumn{2}{|c}{$(32: 1)$} \\
\hline $1936 \sim 1956^{121}$ & 55 & 9 \\
\hline $1966 \sim 1971^{131}$ & 101 & 10 \\
\hline 13 & \multicolumn{2}{|c}{$(6.1: 1)$} \\
\hline $1970 \sim 1977^{171}$ & 38 & 0 \\
\hline
\end{tabular}

\begin{tabular}{|c|c|c|}
\hline & 上部尿石 & 下部尿石 \\
\hline \multirow{2}{*}{${ }_{(\text {タイ }}^{1956 〜 1962^{18)}}$} & 25 & 2794 \\
\hline & \multicolumn{2}{|c|}{$(1: 112)$} \\
\hline \multirow{2}{*}{$\begin{array}{c}1957 \sim 1967^{19)} \\
(\text { イラン) }\end{array}$} & 41 & 151 \\
\hline & \multicolumn{2}{|c|}{$(1: 3.7)$} \\
\hline
\end{tabular}

ではじめて上部優位 $(2: 1)$ となり, その後徐々にそ の差が影著となり早くから上部尿石の多い欧米先進国の パターン ${ }^{12) 16)}$ に近似してきている。一方結石多発地域で は現在でも下部尿石が圧倒的に多い(18)19（表 3 ）. 自験 例ではサンゴ状結石は腎結石 9 例中 6 例之半数以上を占 めて打りいずれも男子例であつた．本邦の全年龄層に拈 ける統計ではサンゴ状結石は女子に多く，また全腎結石 に対する割合は11〜13\%と低く ${ }^{2021)}$ ，また小児サンゴ状 結石の報告をみても Daeschner ら ${ }^{9)}$ の2/15, Noronha ら ${ }^{22)}$ の5/19であり，自験小児尿石に特ける 1 つの特徵といえ よう.

成人の上部尿石の扣もな臨床症状は疼痛，血尿であ る. 自験例の上部尿石では肉服的血尿が $6 / 13$, 側腹痛 $3 / 13$, 発熱 $2 / 13$ と成人例とほ涪同じである. しかし症例 $5 ， 12 ， 15$ の乳児がいずれも頻回の発熱を主訴としてお り, しかもこれらの症例を含め初発症状出現より診断ま でに最長36力月 (症例14), 平均8.6力月を要している点 は注意を要する.膿尿, 腹痛などのほか不明の発熱, 背 部痛, 呕気 食欲不振, 渧啼, 発育不良などの症状が前 面に出ることもあり, これらの症状が持続する場合，尿 石の存在を念頭に打くことが早期診断の手がかりとなる 5.

小児尿石の観血的治療は原則的に成人例と同じで腎臟 の保存につとめるべきである. 1957年 $\mathrm{Myers}^{12}$ は は77症例 に109回の手術を施行し，このらち半腎摘も含め腎摘除 術が22回と報告しているが，1979年 Sinno ら ${ }^{11}$ は31例に extended pyelolithotomy などを抢こない腎保存につとめ 1 例の腎摘も持こなわなかつたと報告し, 他側腎への再 発の可能性を考咴摘は絶対に避けるべきだと強調して いる. また観血的治療にあたつては結石発生の原因とな つている通過障害などの尿路系の異常があ机ば矯正する 必要がある. 症例14（図1，2）は結石摘出と同時に尿

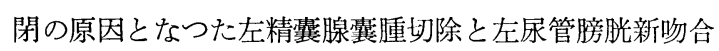
術をおこなつた例である゙

$\operatorname{Drach}^{1)}$ や Malek ${ }^{2)}$ による以前は小児結石の半数が尿 酸扣よび尿酸塩といわれていたが，近年は尿酸結石の占 める割合は激減している。.Paulson ${ }^{23}$ らによれば小児尿 石41例の分析で葆酸カルシウム 28 , 蓚酸カルシウム・燐 酸カルシウム 3 と蓚酸塩系結石が $75.6 \%$ を占め, シス チン 6 , 尿酸 4 と報告し, Sinno $5^{11}$ も葆酸塩系結石が $79.1 \%$ と成人例の傾向に類似した分析結果である. 一方 Malek and Kalalis ${ }^{14)}$ によれば60例の分析で燐酸塩系結 石 26 例， $43.3 \%$, 蓚酸塩系結石 26 例, $43.3 \%$, シスチン 6 
例，㽷酸 2 例で燐酸塩系結石の頻度が高いと報告してい る. 自験例10例の分析でも燐酸塩系が 4 例と一番多かつ た.これは後述するように尿路感染に起因していると思 われる. シスチンやキサンチン結石をそれぞれ 2 例， 1 例経験しているが，このような先天的代謝異常にもとづ き発症する結石が多いのが小児尿石の特徴である.

小児尿石は成人例に比し結石発症の原因疾患の存在す る率が高いといわれている. そのため結石除去だけでな く，原因を解明，是正することが重要である. Malek and Kalalis ${ }^{14)}$ は小児尿石症78例の検討で代謝性疾患によ るもの29例，尿路感染によるもの 25 例と $69.2 \%$ に原因疾 患が存在したと報告している. また Sinno ら ${ }^{11)}$ は54例中 感染16例，代謝性疾患14例，尿路奇形13例之79.6\%に原 因疾患が明らかになつたと述べている. 本邦では時任 $5^{8)}$ が12例中 2 例， $16.7 \%$ (いずれもシスチン尿症）に のみ原因疾患が明らかであつたと報告している. 自験例 の17例では 9 例， $52.9 \%$ に原因疾患が明らかとなつた. その内訳は代謝性疾患 3 例，尿路奇形をともなら尿路感 染 3 例，長期臥床 1 例のほか薬剂の副作用によるもの 2 例が注目される. 1 例は症例 8 のD 抵抗性クル病に対 するVD大量投与例 ${ }^{24)}$ ，他の 1 例は症例13の形成不全性 貧血に対するステロイド投与例である．このように骨代 謝に影響を特よぼす薬阂投与中は結石発症に注意する必 要がある.な拉われわれの症例は症例 6，16を除いて初 診時15例に尿感染をみたが，感染が結石の原因か結果か は決定しがたいため尿路奇形・閉塞に感染をともなつた 3 例を除き, 原因として感染例に加えなかつた.

小児尿石症の家族発生に対する詳細な検討をおこなつ た報告はないが40〜 50\%前後といわれている ${ }^{11) 23)}$. 自験 例17例では遺伝性疾患にもとずくものが 3 例あつたにも かかわらず症例 1 のシスチン尿症例に家族発生をみたに すぎない. 全結石例の再発は高安ら ${ }^{20)}$ によれ゙ 5 年後 $21.9 \pm 2.9 \%, 10$ 年後 $38.2 \pm 4.7 \%$ であ. 小児尿石症の 再発率は時任ら ${ }^{8)}$ は文献的には15〜40\%であるが，彼ら 自身の10症例では再発をみていないといら。ただし追跡 期間の記載がない. 自験17例のうち結石 free の状態とな しえた12例の平均追跡期間は9.6年で 1 例（症例 2) に のみ再発がみられ再発率は8.3\%と低率である. 自験例 では症例 9 のシスチン尿症に重曹と一時期 D-penicillamine を投与した以外は水分多量摄取の生活指導と定期 的な経過観察により, 尿感染の早期コントロールをおこ なつているのみであるが予想外に再発率が低かつた。 し かしその正確な理由は定かではない，最後に小児尿石症:
表 4 Routine diagnostic tests in urolithiasis

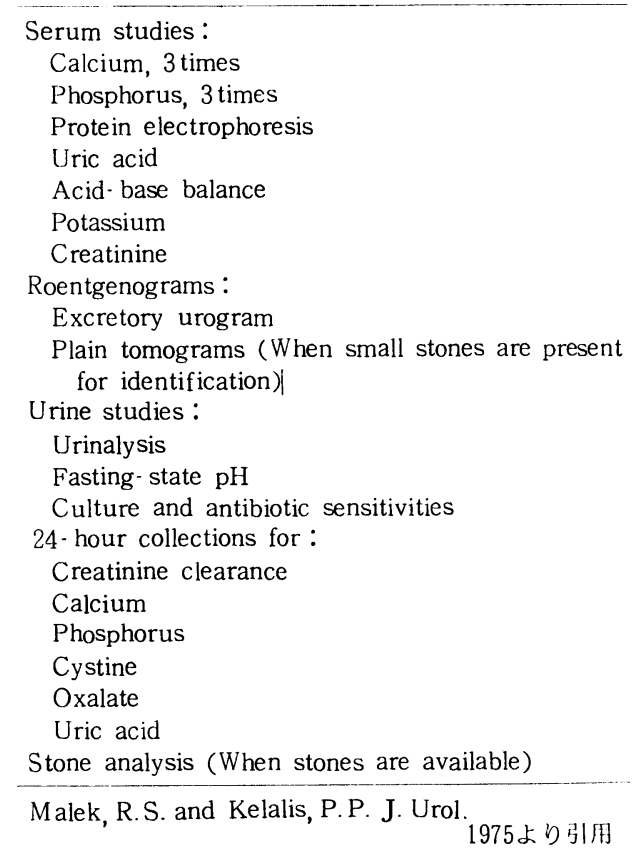

の骖断について述べる。一般に尿石診断は尿検查，腎膀 脱部単純撮影, 排泄性腎孟造影で容易である. しかしX 線院性結石の疑いの場合, 乳幼児例では逆行性操作が困 難なためしばしば診断に苦労する.このような症例では 結石の診断確定と腎盘腎杯内の存在状況を把握する上で 腹部 CT が非常に有効と考学られる（図10，11）。また 小児尿石の診断にあたつては，前述したように成人例に 比し結石発症の原因疾患の存在率が高いので, 結石診断 だけでなく原因疾患を解明することが重要である。その ため小児尿石の診断には前もつて計画したスケジュー ルにのつとつて検索することが望ましい. Malek and Kalalis $^{14)}$ は表 4 亿示す項目を系統的に検查をすすめる ことを提唱している.われわれは最近これにX線陰性結 石の疑いのある例には腹部 CT を加えている.

\section{結 語}

当科に持ける過去 15 年問の小児尿石证について報售し た.

1）症例数は17例で，この間の全尿石怔 1,047 例の1.6 \%に相当する.

2）年齢は 1 歳未満 2 例， $1 \sim 5$ 歳 6 例， $6 \sim 10$ 歳 6 例, $10 \sim 15$ 歳 3 例で, 男女比は2.4: 1 であつた.

3）絬石部位は上部尿石13例（腎結石 9 例，尿管結石 
4 例), 下部尿石 2 例（膀胱結石 2 例）, 上部と下部尿石 2 例で上部と下部の比率は6.5：1であつた. サンゴ状 結石は 6 例で腎結石の $66.7 \%$ をめた.

4）上部尿石13例の臨床症状は肉眠的血尿 6 例, 発熱 2 例，側腹痛 3 例，尿閉 1 例，失禁 1 例であつた。 下 部尿石 2 例は膀胱刺激症状，上部之下部尿石 2 例は発熱 1 例，上部之下部尿石 2 例は発熱 1 例，膀腃刺激症状 1 例であつた。

5）全例他医からの紹介例で, 初発症状出現から当科 受診をで最短 1 日, 最長 36 月で, 平均 8.6 力を要し た.

6）観血的治療は11例に13回おこなわれた．内容は婜 摘除術 2 , 腎部分切除術 1 , 腎・腎孟切石術 1 , 腎㙉切 石術 2 , 尿管切石術 2 , 膀脱切石術 4 , 尿道結石摘出術 1 であつた. 自然排出 2 例, 残りの 4 例のうち 3 例は経 過観察中で 1 例が追跡不能となつた.

7）結石成分の分析は 10 症例に施行. 蓚酸カルシウム ・燐酸カルシウム 2 例, 蓚酸カルシウム 1 例, 燐酸カル シム 2 例, 燐酸マグネシウム・アンモニウム 2 例, シス チン 2 例, キサンチン 1 例であつた.

8） 17 例中 9 例， $52.9 \%$ に原因疾患が存在した．との 内訳はシスチン尿症 2 , キサンチン尿症 1 , 薬剤の副作 用 2 , 長期臥床 1 , 尿路奇形をともなら尿流停滞・尿路 感染 3 であつた.

9）結石 free の状態となつた12例の平均追跡期間は 9.6 年でこの間の再発は 1 例であり, 再発率は $8.3 \%$ であ つた.

本論文の要旨は第10回日本腎㵴学会東部部会で報告し た。また症例15は第304回日本小児科学会東京都地方会 講話会で 1 例報告した。

症例を紹介いたたいた当院小児科, 整形外科の諸先生 に深謝いたします。

\section{文 献}

1) Drach, G.W.: Urinary lithiasis. In Campbell's Urology, 4th ed., Vol I p. 861, W.B. Saunders Co., Philadelphia, 1978.

2) Malek, R.S.: Urolithiasis. In Clinical Pediatric Urology, p. 865-895, W.B. Saunders Co., Philadelphia, 1976.

3）横山正夫, 石田肇, 鈴木 徹, 阿曾佳郎: 左 尿管膀胱移行部狭窄おょび精囊腺囊腫の合併症 例. 日泌尿会誌, 67, 137, 1976 。

4) Yokoyama, M., Suzuki, T., Aso, Y. and Akaoka, I.: A xanthine stone in a xanthinuric boy: A biochemical case study. J. Urol., 118,
$651-653,1977$.

5) 平石攻治, 山下利幸, 中村章一郎, 辻村玄弘, 黒川一男：尿路結石症の統計的観察. 昭和38 49年の教室例について。西日泌尿, 37, 918922, 1975.

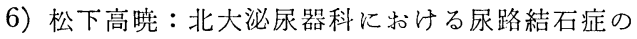
統計的観察 (昭和 $34 \sim$ 昭和 50 年). 北海道医誌, 53, 321-327, 1978.

7）藤沢保仁, 大島一寛, 坂本公孝: 小児の尿路結 石症，皮膚と泌尿，30，869-874，1968.

8) 時任高洋, 野田進士, 江藤耕作: 小児尿路結石 症について，西日泌尿，39，55-63，1977.

9) Daeschner, C.W., Singleton, E.B. and Curtis, J.C.: Urinaly tract calculi and nephrocalcinosis in infants and children. J. Pediat., 57, 721$732,1960$.

10) Bass, H.N. and Emanuel, B.: Nephrolithiasis in childhood. J. Urol., 95, 749-753, 1966.

11) Sinno, K., Boyce, W.H. and Resnick, M.I.: Childhood urolithiasis. J. Urol., 121, 662 -664, 1979.

12) Myers, N.A.A.: Urolithiasis in childhood. Arch. Dis. Child., 32, 48-57, 1957.

13) Ghazali, S., Barratt, T.M. and Williams, D.I.: Arch. Dis. Child., 48, 291-295, 1973.

14) Malek, R.S. and Kelalis, P.P.: Pediatric nephrolithiasis. J. Urol., 113, 545-551, 1975.

15）辻一郎：小児泌尿器科の臨床, p152-158, 金 原出版, 東京, 1962 .

16) Winkel Smith, C.C.: On urinary lithiasis in childhood. A clinical study of 71 cases of urinary calculi in children. Acta. Chir. Scand., 90, 179-185, 1944.

17) Churchill, D.N., Maloney, C.M., Nolan, R., Gault, M.H. and Winsor, G.: Pediatric urolithiasis in the 1970s. J. Urol., 123, 237238, 1980.

18) Chutikorn, C., Valyasevi, A. and Halstead, S.B.: Studies of bladder stone disease in Thailand. II. Hospital experience. Urolithasis at Ubol Provincial Hospital, 1956-1962. Am. J. Clin. Nutr., 20, 1320-1328, 1967.

19) Gharib, R.: Lithiasis in the urinary tract of children. General review based on observations in 167 affected Iranian children. Clin. Pediat., 9, 157-164, 1970.

20）高安久雄, 小川秋実, 上野精, 宮下厚, 河 村 毅, 東原英二, 北村唯一, 小林克己, 富永 登志, 藤目 真: 尿路結石の臨床統計。 日泌尿 会誌, 69, 436-442，1978.

21）河村 毅, 国沢義隆, 大谷幹伸, 柳沢良三, 篠 原 充, 小松秀樹, 東海林文夫, 石田 肇, 福 谷恵子, 横山正夫 : 東大分院泌尿器科外来に打 ける昭和 45 年より昭和 54 年までの尿路結石症の 
統計的観察.

臨泌, 34, 963-968, 1980.

22) Noronha, R.F.X., Gregory, J.G. and Duke, J.J.: Urolithiasis in children. J. Urol., 121, 478-479, 1979.

23) Paulson, D.F., Glenn, J.F., Hughes, J., Roberts, L.C. and Coppridge, A.J.: Pediatric uro- lithiasis. J. Urol., 108, 811-814, 1972.

24) 徳汇章彦, 北川竜一, 岩動孝一郎, 加納勝利, 小峰志訓, 吉川靖三: ビタミン D抵抗性クル病 に伴う腎結石の 1 例。日泌尿会誌, $63,985,19$ 72 .

（1980年 7 月 3 日受付） 